\title{
Influence of Plant Density and Nitrogen Fertilizer Rates on Yield and Yield Components of Beetroot (Beta vulgaris L.)
}

\author{
Zerihun Sinta iD and Gezahegn Garo \\ Arba Minch University, College of Agricultural Science, P.O. Box 21, Arba Minch, Ethiopia \\ Correspondence should be addressed to Zerihun Sinta; zesishe2003@yahoo.com
}

Received 26 March 2021; Revised 30 July 2021; Accepted 26 August 2021; Published 7 September 2021

Academic Editor: Maria Serrano

Copyright (C) 2021 Zerihun Sinta and Gezahegn Garo. This is an open access article distributed under the Creative Commons Attribution License, which permits unrestricted use, distribution, and reproduction in any medium, provided the original work is properly cited.

\begin{abstract}
Ethiopia is endowed with diverse agroecologies suitable for the production of tropical, subtropical, and temperate vegetables. Agronomic practices such as plant density and fertilizer management are known to affect the crop environment, which influences the growth and ultimately the yield. So far limited research has been done on plant density determination and rate of nitrogen fertilizer in Ethiopia in general and the study area in particular. Thus, this experiment was carried out to evaluate the influence of plant density and nitrogen fertilizer rates on the yield and yield components of beetroot (Beta vulgaris L.). Four plant densities (133 333, 100 000, 80000 , and 66666 plants per hectare) and four nitrogen (N) fertilizer rates $\left(0,46,92\right.$, and $\left.138 \mathrm{~kg} \mathrm{Nha}^{-1}\right)$ were arranged in a factorial combination in a randomized complete block design with three replications. The results revealed that the main and interaction effects of plant density and nitrogen fertilizer rates on total root yield, root length, root fresh weight, root diameter, and total soluble solute of beetroot were significant. The highest root yield of beetroot was achieved from the combination of 66666,80000 , and 100000 plant ha $^{-1}$ with $92 \mathrm{~kg} \mathrm{~N} \mathrm{ha}^{-1}$, whereas the lowest root yield of beet was obtained from the combination of $0 \mathrm{~kg} \mathrm{~N} \mathrm{ha}^{-1}$ with a planting density of 133333 plants ha ${ }^{-1}$. The economic analysis showed that higher net benefit and marginal rate of return were obtained from the application of $92 \mathrm{~kg} \mathrm{~N} \mathrm{ha}^{-1}$ with plant densities of $66666 \mathrm{plants} \mathrm{ha}^{-1}$. In order to prevent excessive production costs, the use of 66666 plants ha $^{-1}$ combined with the application of $92 \mathrm{~kg} \mathrm{~N}^{-1}$ is recommended.
\end{abstract}

\section{Introduction}

Beetroot (Beta vulgaris L.) is a member of the Chenopodiaceous family which has silver beet, sugar beet, and fodder beet [1]. Beetroot has three basic varieties: chard, grown specifically for its leaves; beets, grown for their bulbous root and leaves (with varieties in white, yellow, and red roots); and sugar beets, grown for producing sugar from the long thick roots. Beetroot produces green tops and a swollen root during its first growing season. It is highly productive and usually free of pests and diseases [2]. Most types of beet plants are tolerant to heat but thrive in environments with temperatures between 15 and $18^{\circ} \mathrm{C}$ in full sun and can also withstand cold temperatures [3]. It attains the best color, texture, and quality in cool weather conditions. Red beets are also widely used in the food industry [4] and are rich in several vitamins; hence, they are ideal vegetables for health-conscious people [1].
Agronomic practices such as plant density and fertilizer management are known to affect the crop environment, which influences the growth and ultimately the yield $[5,6]$. Optimum population and nitrogen levels should be maintained to exploit maximum natural resources, such as nutrients, sunlight, and soil moisture, to ensure satisfactory growth and yield. The plant density of cultivated land is a major factor in determining the quality and quantity of the beetroots. Optimum plant density provides a larger area which allows the plant a sufficient quantity of water and light and thus raises the efficiency of photosynthesis thereby increasing the productivity of beetroot [7]. Research evidence suggests that planting density affects the growth and yield of beetroot. According to Ramazan [8], a higher root yield was obtained at a planting density of 111111 plants $\mathrm{ha}^{-1}$ compared to a population per hectare of 55555 plants. In addition, Sogut and Arioglu [9] reported that plant 
density at 148148,111111 , and 88889 produced higher root yields than 74074 and 63492 plants per hectare. NemeatAlla [10] reported that planting sugar at a population of 100 000 plants ha ${ }^{-1}$ caused significant increases in root diameter but did not affect root length and total soluble solids. On the other hand, Bhullar et al. [11] stated that the plant population of 100000 plants ha $^{-1}$ produced the lowest beetroot diameter and highest root length and root yields.

Nitrogen $(\mathrm{N})$ is one of the most important nutrients in determining plant growth and crop yield [12]. It is a component of proteins, enzymes, and vitamins in plants as well as many structural, genetic, and metabolic compounds (chlorophyll) in plant cells and is required for biomass production [13]. Most farmers apply $\mathrm{N}$ fertilizer to increase crop yields. Insufficient supply of $\mathrm{N}$ can reduce plant $\mathrm{N}$ content and rate of photosynthesis [14] and concomitantly reduce plant growth and quality of harvestable materials [15]. The optimal application of $\mathrm{N}$ fertilizers positively impacts production. However, oversupply of $\mathrm{N}$ does not always lead to increased yield, and it might actually result in reduced growth and yield. Excessive applications of $\mathrm{N}$ fertilizers result in delayed maturity and competition between sink (tubers) and supply (leaves) and may lower yields [16]. Excessive $\mathrm{N}$ application does not only delay plant maturity but limits the formation of storage organs, especially for crops where roots and tubers are harvested. This leads to lower yields and may reduce the postharvest root quality in terms of flavor and sugar content, $\mathrm{pH}$, and firmness [17]. Different scholars recommended different rates of $\mathrm{N}$ fertilizer for beetroot. El-Hosary et al. $[18,19]$ found that increasing $\mathrm{N}$ fertilizer levels caused significant differences in yield, yield components, and quality of sugar beet. Seadh [20] stated that growth characters, yields, and its components significantly increased as the $\mathrm{N}$ fertilizer level increased. Khalil [21] found that increasing $\mathrm{N}$ levels significantly increased root length, root diameter, root fresh weight, and root yield plant ${ }^{-1}$. Abdou et al. [22] indicated that increasing $\mathrm{N}$ fertilizer level significantly increased root fresh weight, root length, and diameter as well as total soluble solutes (TSS) and root yield. Ouda [23] found that root diameter, root length, root fresh weights as well as root yield, and TSS percentage were increased by raising $\mathrm{N}$ levels. Similarly, Abdou [24] reported increasing N levels significantly reduced TSS percentages. In contrast, other studies showed that TSS was significantly reduced when $\mathrm{N}$ rates were increased $[25,26]$.

Ethiopia is endowed with diverse agroecologies appropriate for the production of tropical, subtropical, and temperate vegetables within the lowlands, midlands, and highlands [27]. The warm-season vegetables are produced in hot semiarid areas under both dryland and irrigation, while the highland offers favorable growing conditions for the production of cool-season vegetables such as kale (Brassica oleracea L. var. acephala), cabbage (Brassica oleracea L. var. capitata), garlic (Allium sativum L.), shallot (Allium cepa L. var. aggregatum), carrot (Daucus carota L.), and beetroot $[27,28]$. In Ethiopia in general and in the study area in particular, beetroot is relatively new and a lot of people do not know how to grow it while it is increasingly gaining a high level of economic importance in both generation of income and provision of good nutrition. The major constraints in the production of beetroot in Ethiopia are poor agronomic practices including the use of inappropriate planting density and $\mathrm{N}$ fertilizer rates due to lack of adequate information on its cultivation which reduces the yield and quality of the crop. Therefore, it is necessary to establish the optimum plant density and $\mathrm{N}$ application rates for the increased weight and quality of beetroot. The objectives of this study were to evaluate the influence of plant density and $\mathrm{N}$ fertilizer rates on the yield and quality of beetroot.

\section{Materials and Methods}

2.1. Description of the Experimental Site. The experiment was conducted at Arba Minch University Gircha Highland Fruit and Vegetable Research Center, Ethiopia. It is located at $37^{\circ}$ $60^{\prime} \mathrm{E}$ and $6^{\circ} 13^{\prime} \mathrm{N}$ with an altitude ranging from 3005 masl and a mean annual rainfall of $1800 \mathrm{~mm}$. The mean annual temperature of the area is $22.5^{\circ} \mathrm{C}$. The soil used in the study is clay loam with $\mathrm{pH} \quad 4.8,0.308 \% \mathrm{~N}, \quad 3.2 \mathrm{mg} \mathrm{L}^{-1} \mathrm{P}$, $11.2 \mathrm{mg} \mathrm{L}^{-1} \mathrm{~K}$, and $2.4 \%$ OC $[29,30]$.

2.2. Experimental Treatments, Design, and Management. The experiment was laid out as a randomized complete block design (RCBD) with factorial arrangements of $4 \times 4=16$ treatment combinations and three replications for two consecutive years (2018 and 2019). The treatments consisted of four plant densities, namely, $133333,100000,80000$, and 66666 plants ha ${ }^{-1}$ and four rates of $\mathrm{N}$ fertilizer, namely, 0 , 46,92 , and $138 \mathrm{~kg} \mathrm{~N} \mathrm{ha}^{-1}$. Each plot was $3 \mathrm{~m} \times 3 \mathrm{~m}$ in size consisting of six rows. The distances between plots and replications were 0.5 and $1.0 \mathrm{~m}$, respectively. Ground lime $\left(\mathrm{CaCo}_{3}\right)$ at the rate of $2.25 \mathrm{tha}^{-1}$ was added one month before planting to reduce soil acidity, and phosphorus (P) fertilizer was applied uniformly to all experimental plots at the rate of $46 \mathrm{~kg} \mathrm{ha}^{-1}$. Half of $\mathrm{N}$ for the respective treatments and all $\mathrm{P}$ were applied at the time of seed sowing, and the remaining $\mathrm{N}$ was applied 45 days after sowing. Urea and Triple Super Phosphate (TSP) were used as the sources of N and $\mathrm{P}$ fertilizer, respectively, and a beetroot variety called Detroit red was planted. All other agronomic practices were kept uniform for all experimental units.

2.3. Data Collection. Data on all parameters were taken after 97 days after seeding. Data were collected on total root yield $\left(\mathrm{t} \mathrm{ha}{ }^{-1}\right.$ ) by weighing the below-ground beetroot parts after washing. Total fresh mass $\left(\mathrm{t} \mathrm{ha}{ }^{-1}\right)$ was determined by weighing the mass of the entire plant (above- and belowground portion) after washing. Root length $(\mathrm{cm})$ and root diameter $(\mathrm{cm})$ were determined by measuring at right angles to the vertical and horizontal axis, respectively, using a caliper, model CD 8. Total soluble solids of roots were measured using a hand refractometer, model REF-113ATC.

2.4. Data Analysis. Analysis of variance (ANOVA) was carried out for all data using SAS version 9.1 software [31]. Homogeneity of error variance was tested using the F test as 
described by Gomez and Gomez [32], and the F test was not significant. Thus, a combined analysis of the two-year data was performed. The least Significant Difference (LSD) at the $5 \%$ probability level was carried out for mean separation.

2.5. Partial Budget Analysis. The partial budget analysis was carried out by using the methodology described in CIMMYT [33] in which prevailing market prices for inputs at sowing and outputs at harvesting were used. All costs and benefits were calculated on a hectare basis in Ethiopian Birr (ETB). The mean grain yields were adjusted down by subtracting $10 \%$ to approach the real production conditions. Total variable costs were calculated as cost of inputs $(100 \mathrm{~kg}$ Urea/1390 ETB + one $\mathrm{kg}$ beetroot seed/880 ETB) plus fertilizer application and seed sowing costs ( 75 birrs/person/day). The current open market price of $100 \mathrm{~kg}$ root yield was $700 \mathrm{ETB}$, and the mean root yield of each treatment was calculated. The net benefit (NB) was obtained by subtracting total variable costs from the gross benefit. In addition, the marginal rate of return was also calculated as a change in net benefit/change in total variable $\operatorname{cost} \times 100$. For a treatment to be considered as worthwhile to farmers, with the highest net benefit and marginal rate of return, $>100 \%$ was considered for the recommendation [34].

\section{Results and Discussion}

3.1. Summary of ANOVA. A summary of ANOVA for the attributes measured in this study is shown in Table 1. According to the analysis variance, there were highly significant $(P<0.01)$ differences between levels of experimental factors for all studied traits. Interaction of plant density and nitrogen fertilizer was highly significant $(P<0.01)$ on root yield and root length, but root fresh weight, root diameter, and TSS were not significant $(P>0.05)$.

3.2. Root Yield. The higher root yield of beet was achieved from the combination of $92 \mathrm{~kg} \mathrm{Nha}^{-1}$ with a plant density of 6666680000 and 100000 plant ha $^{-1}$ whereas the lowest root yield of beet was obtained from the combination of $0 \mathrm{~kg} \mathrm{Nha}^{-1}$ with a planting density of 133333 plants ha ${ }^{-1}$ (Figure 1). Increasing the nitrogen level of the fertilizers up to $92 \mathrm{~kg} \mathrm{Nha}^{-1}$ increased the total yield of beetroot and the trend decreased at the highest level $\left(138 \mathrm{~kg} \mathrm{Nha}^{-1}\right)$. This might be due to more available nutrients which increased all the growth and yield attributes of the crop that finally led to increased beetroot yield [35]. Leilah et al. [36] reported that root yield increase is caused by high $\mathrm{N}$ levels due to $\mathrm{N}$ playing an important role in enhancing growth, chlorophyll formation, the photosynthesis process, and other variables contributing to yield improvement. Hamidia et al. [37] stated that biomass yield decreases progressively as the number of plants increases in a given area because the production of the individual plant is reduced. Moreover, Khaiti [38] mentioned that the use of a high population increases interplant competition for light, water, and nutrients, which can be detrimental to final yield. ElHosary et al. [18-20] stated that root yields of sugar beet are significantly increased as nitrogen fertilizer levels increased.
3.3. Root Length. Root length was significantly higher where $\mathrm{N}$ fertilizer was applied at $92 \mathrm{~kg} \mathrm{Nha}^{-1}$ combined with a plant density of 80000 plants ha ${ }^{-1}$ than other treatment combinations used, except where $138 \mathrm{~kg} \mathrm{Nha}^{-1}$ and 80000 plants $\mathrm{ha}^{-1}$ were used (Figure 2). On the other hand, the lowest root length was recorded where $\mathrm{N}$ fertilizer was applied at $0 \mathrm{~kg} \mathrm{~N} \mathrm{ha}^{-1}$ with a plant density of 133333 plants ha ${ }^{-1}$. This is because at a wide spacing there will be more empty space and no competition for nutrients, water, and light that affect photosynthesis. Sadre et al. [39] mentioned that the increase in root length can be explained through the fact that the higher biomass in treatments having comparatively less plant density was possibly due to optimum utilization of soil and other environmental resources with lower competition by the crop. Mustafa [40] suggested that the nitrogen element may be playing an important role in increasing cell elongation and cell division. Abdou et al. [21, 22] stated that increasing nitrogen levels significantly increased root length. Amin [41] reported that the application of $\mathrm{N}$ fertilizer at high rates increases root length.

3.4. Root Fresh Weight per Plant. The data in Table 2 indicate that the plant density of 66666 plants ha $^{-1}$ had a significantly higher root fresh weight of beetroot than the other plant density treatments while 133333 plants ha ${ }^{-1}$ resulted in the lowest root fresh weight of beetroot. The plant densities of 80 000 plants $\mathrm{ha}^{-1}$ increased yields significantly over the crop that was sown at 133333 and 100000 plants ha ${ }^{-1}$. The root fresh weight per plant at a wide spacing was greater than the fresh weight at narrow plant spacing. This is because the nutrients, water, and sunlight can be received optimally and the competition between plants can be minimized in widely spaced rows, thereby increasing the yield of plants in the form of arrowroot tubers [42]. Root fresh weight increased with increasing levels of $\mathrm{N}$ (Table 2). The highest root fresh weight was obtained from the application of 92 and $138 \mathrm{~kg} \mathrm{Nha}^{-1}$, while the lowest root fresh weight was obtained from $0 \mathrm{~kg} \mathrm{Nha}^{-1}$. At $138 \mathrm{~kg} \mathrm{Nha}^{-1}$, the root fresh weight was not significantly different from that obtained at the $46 \mathrm{~kg} \mathrm{~N} \mathrm{ha}^{-1}$ application rates. In addition, no significant differences in root fresh weight were found between $46 \mathrm{~kg} \mathrm{Nha}^{-1}$ and control $\left(0 \mathrm{~kg} \mathrm{Nha}^{-1}\right)$. The increase in root fresh weight per plant was accompanied by the increase in root dimensions (i.e., length and diameter). This is maybe the effective role of nitrogen fertilizer on cell division and elongation which consequently reflected on root fresh weight [22]. Supplying beetroot plants with $\mathrm{N}$ fertilizer up to $100 \mathrm{~kg} \mathrm{Nha}^{-1}$ increased root fresh weight [43]. Turk [44] found that the application of $\mathrm{N}$ fertilizer had a significant effect on beetroot fresh weight.

3.5. Root Diameter. The plant density of 66666 plants ha $^{-1}$ had a significantly higher root diameter of beetroot than the other plant densities while 100000 plants ha ${ }^{-1}$ resulted in the lowest root diameter of beetroot (Table 2). The data also indicate that crops sown at 80000 plants ha $^{-1}$ resulted in higher root diameter compared with the crop sown at 133333 and 100000 plants ha ${ }^{-1}$. However, nonsignificant differences were observed 
TABLE 1: Combined analysis of variance showing mean squares for root yield and other parameters of beetroot influenced by plant density and nitrogen fertilizer rates.

\begin{tabular}{lccccc}
\hline \multirow{2}{*}{ Source variation } & & \multicolumn{3}{c}{ Mean square } \\
& Root yield & Root fresh weight & Root length & Root diameter & Total soluble solute \\
\hline Plant density (PD) & $10.956^{* *}$ & $3318.92^{* *}$ & $193.08^{* *}$ & $3.813^{* *}$ & $18.271^{* *}$ \\
Nitrogen (N) & $35.806^{* *}$ & $237.28^{* *}$ & $218.75^{* *}$ & $9.220^{* *}$ & $1.646^{* *}$ \\
PD $*$ N & $0.786^{* *}$ & $5.21^{\text {ns }}$ & $10.49^{* *}$ & $0.331^{\text {ns }}$ & $0.048^{\text {ns }}$ \\
Error & 0.258 & 39.37 & 3.59 & 0.173 & 0.062 \\
CV $\%$ & 7.49 & 11.33 & 4.3 & 7.18 & 3.61 \\
\hline
\end{tabular}

Where, CV stand for Coefficient of Variation; ${ }^{* *}$ stand for significance at $P<0.01$, respectively; NS stands for non-significant at $P<0.05$.

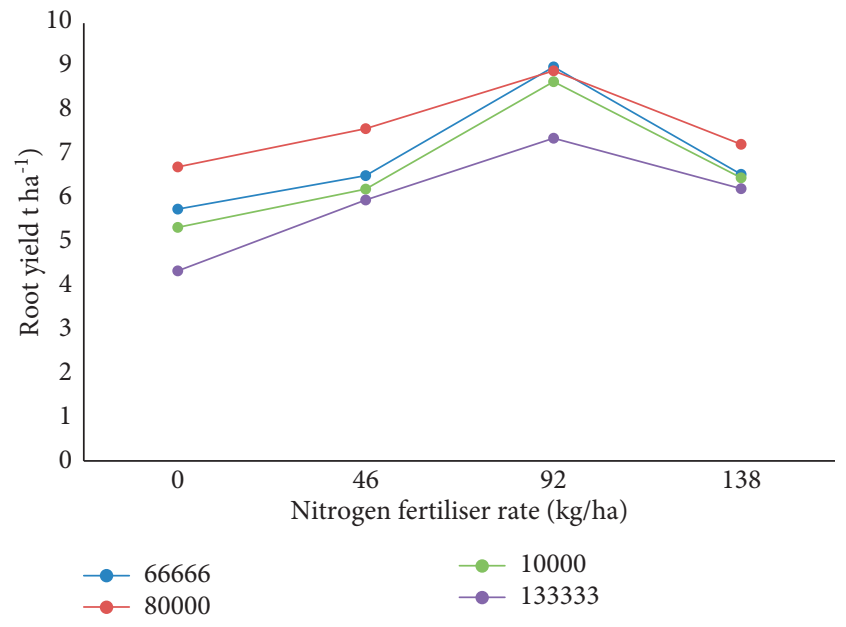

FIGURE 1: Interaction effects of plant density and nitrogen fertilizer rates on root yield $\left(\mathrm{t} \mathrm{ha}^{-1}\right)$ of beetroot.

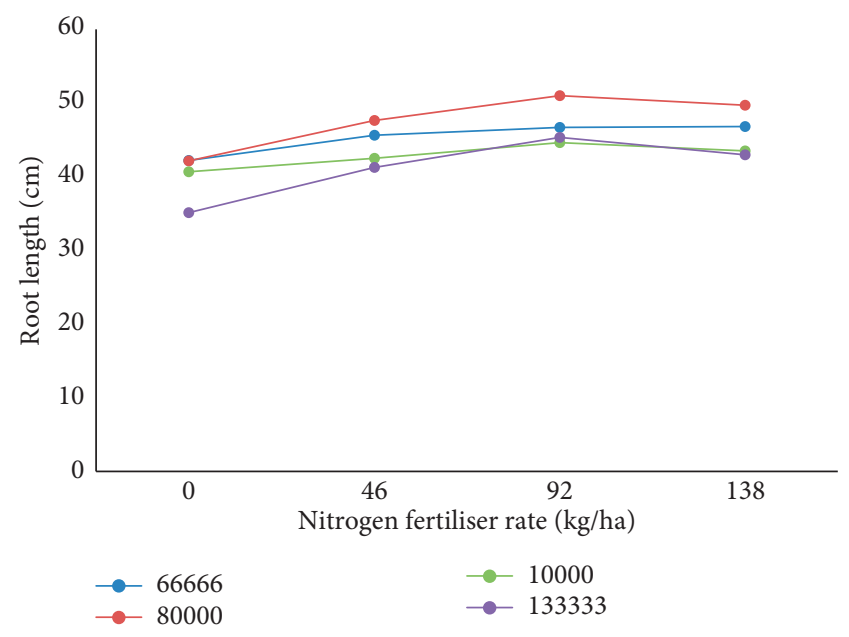

FIGURE 2: Interaction effects of plant density and nitrogen fertilizer rates on root length $(\mathrm{cm})$ of beetroot.

in root diameter where the crop was sown at 133333 and 100 000 plants ha ${ }^{-1}$. These results are confirmed with the findings of [45] which stated that wider row spacing gave more space to roots to grow horizontally and root diameter was wider. Kogali et al. [46] stated that wider row spacing resulted in wider root diameter. Heitholt and Sassenrath-Cole [47] reported that spacing affects the root diameter of beetroot. Beetroot diameter increased with increasing rates of $\mathrm{N}$ (Table 2). Diameter of plants receiving 92 and $138 \mathrm{~kg} \mathrm{Nha}^{-1}$ was significantly wider than those that did not receive $\mathrm{N}$ applications and those that received $46 \mathrm{~kg} \mathrm{Nha}^{-1}$. Nitrogen at $46 \mathrm{~kg} \mathrm{Nha}^{-1}$ resulted in a significantly wider beetroot diameter than the control. Application of $\mathrm{N}$ at 92 and $138 \mathrm{~kg} \mathrm{ha}^{-1}$ did not differ significantly in influencing the beet diameter. The reason for maximum beet diameter in plants receiving more $\mathrm{N}$ may be due to the fact that these plants were more healthy and vigorous than others [48]. These results are confirmed by [44] who found that increasing the $\mathrm{N}$ fertilizer rates increased beetroot diameter.

3.6. Total Soluble Solute (TSS). Plant density of 66666 plants $\mathrm{ha}^{-1}$ had a significantly higher TSS concentration while 133 333 plants $\mathrm{ha}^{-1}$ resulted in the lowest TSS concentration (Table 2). Plant densities of 80000 plants ha $^{-1}$ resulted significantly in higher TSS compared to those of 133333 and 100 000 plants $\mathrm{ha}^{-1}$. The data also indicate that crops that were sown at 100000 plants $\mathrm{ha}^{-1}$ resulted in more TSS than those plants at a density of 133333 plants ha ${ }^{-1}$. The gradual increase in TSS that was accompanied with the decrease in plant populations may be due to the fact that the increase in plant population results in the decrease of sucrose content in beetroots [49]. Kirimi et al. [50] reported that higher TSS obtained at wider spacing might be due to translocation of assimilates (a major constituent of TSS) affected by growing conditions through the rate of assimilating export from the leaves. Nitrogen level significantly influenced TSS of beetroot (Table 2). The application of $\mathrm{N}$ at $138 \mathrm{kgNha}^{-1}$ resulted in significantly more TSS than the control level $\left(0 \mathrm{~kg} \mathrm{Nha}^{-1}\right)$. Total soluble solids of plants receiving $138 \mathrm{~kg} \mathrm{Nha}^{-1}$ were significantly larger than those that received 0,46 , and $92 \mathrm{~kg} \mathrm{Nha}^{-1}$. Nitrogen at $92 \mathrm{~kg} \mathrm{Nha}^{-1}$ levels resulted in more TSS than the control level and $46 \mathrm{~kg} \mathrm{Nha}^{-1}$. Also, the application of Nat $46 \mathrm{~kg} \mathrm{ha}^{-1}$ resulted in more TSS than the control. Nitrogen being a constituent of protein and amino acids directly affects TSS (Kirimi et al. 2011). The paper [23] found that TSS concentration was increased by raising $\mathrm{N}$ levels. The present findings contradicted those of [51] who found that the TSS of carrots was not significantly affected by $\mathrm{N}$ fertilizer treatments. The results also contradicted those of [52] who found that there were no significant differences in the TSS of sugar beet when different levels of $\mathrm{N}$ were applied. Leilah et al. [36] also stated that high $\mathrm{N}$ levels increase the moisture content in root tissue, resulting in lower TSS. Abdou [24] found that increasing $\mathrm{N}$ levels significantly reduced TSS percentages. 
TABLE 2: Mean root fresh weight, root diameter, and total soluble solute of beetroot influenced by plant density and $\mathrm{N}$ fertilizer rates.

\begin{tabular}{|c|c|c|c|}
\hline & Root fresh weight & Root diameter & Total soluble solute \\
\hline \multicolumn{4}{|c|}{ Plant density (plants ha ${ }^{-1}$ ) } \\
\hline 133333 & $42.06^{\mathrm{d}}$ & $5.54^{\mathrm{c}}$ & $5.83^{\mathrm{d}}$ \\
\hline 100000 & $50.16^{\mathrm{c}}$ & $5.45^{\mathrm{c}}$ & $6.57^{\mathrm{c}}$ \\
\hline 80000 & $60.39^{\mathrm{b}}$ & $5.88^{\mathrm{b}}$ & $7.23^{\mathrm{b}}$ \\
\hline 66666 & $68.99^{a}$ & $6.33^{\mathrm{a}}$ & $7.86^{\mathrm{a}}$ \\
\hline $\mathrm{LSD} \leq 0.05$ & 3.62 & 0.24 & \\
\hline \multicolumn{4}{|c|}{ Nitrogen $\left(\mathrm{kg} \mathrm{ha}^{-1}\right)$} \\
\hline 0 & $51.39^{c}$ & $4.93^{\mathrm{c}}$ & $6.57^{\mathrm{d}}$ \\
\hline 46 & $54.56^{\mathrm{bc}}$ & $5.83^{\mathrm{b}}$ & $6.78^{\mathrm{c}}$ \\
\hline 92 & $58.56^{\mathrm{a}}$ & $6.11^{\mathrm{a}}$ & $6.97^{\mathrm{b}}$ \\
\hline 138 & $57.10^{\mathrm{ab}}$ & $6.34^{\mathrm{a}}$ & $7.18^{\mathrm{a}}$ \\
\hline LSD $<0.05$ & 3.62 & 0.24 & 0.14 \\
\hline $\mathrm{CV} \%$ & 11.33 & 7.18 & 3.61 \\
\hline
\end{tabular}

Means followed by the same letter $(s)$ within a column are not statistically different at $P<0.05$.

Table 3: Economic analysis for the effect of plant density and nitrogen fertilizer rates on beetroot.

\begin{tabular}{|c|c|c|c|c|c|}
\hline Treatments & $\begin{array}{l}\text { Root yield adjusted by } 10 \% \\
\qquad\left(\mathrm{~kg} \mathrm{ha}^{-1}\right)\end{array}$ & $\begin{array}{c}\text { Gross income (@7 } \\
\mathrm{ETB} \mathrm{kg}^{-1} \text { ) }\end{array}$ & $\begin{array}{l}\text { Total variable cost } \\
\left(\mathrm{ETB} \mathrm{ha}^{-1}\right)\end{array}$ & $\begin{array}{c}\text { Net benefit (ETB } \\
\left.\mathrm{ha}^{-1}\right)\end{array}$ & $\begin{array}{c}\text { Marginal rate of return } \\
(\text { MRR \%) }\end{array}$ \\
\hline $\mathrm{PD}_{4} \mathrm{NF}_{1}$ & 5159.70 & 36117.90 & 4519.96 & 31597.94 & \\
\hline $\mathrm{PD}_{3} \mathrm{NF}_{1}$ & 6018.30 & 42128.10 & 5424.00 & 36704.10 & 564.82 \\
\hline $\mathrm{PD}_{4} \mathrm{NF}_{2}$ & 5840.10 & 40880.70 & 6059.96 & 34820.74 & $\mathrm{D}$ \\
\hline $\mathrm{PD}_{2} \mathrm{NF}_{1}$ & 4781.70 & 33471.90 & 6780.00 & 26691.90 & $\mathrm{D}$ \\
\hline $\mathrm{PD}_{3} \mathrm{NF}_{2}$ & 6799.50 & 47596.50 & 6964.00 & 40632.50 & 255.09 \\
\hline $\mathrm{PD}_{4} \mathrm{NF}_{3}$ & 8062.20 & 56435.40 & 7599.96 & 48835.44 & 1289.85 \\
\hline $\mathrm{PD}_{2} \mathrm{NF}_{2}$ & 5562.00 & 38934.00 & 8320.00 & 30614.00 & $\mathrm{D}$ \\
\hline $\mathrm{PD}_{3} \mathrm{NF}_{3}$ & 7985.70 & 55899.90 & 8504.00 & 47395.90 & $\mathrm{D}$ \\
\hline $\mathrm{PD}_{1} \mathrm{NF}_{1}$ & 3895.20 & 27266.40 & 9039.98 & 18226.42 & $\mathrm{D}$ \\
\hline $\mathrm{PD}_{4} \mathrm{NF}_{4}$ & 5869.80 & 41088.60 & 9139.96 & 31948.64 & $\mathrm{D}$ \\
\hline $\mathrm{PD}_{2} \mathrm{NF}_{3}$ & 7760.70 & 54324.90 & 9860.00 & 44464.90 & $\mathrm{D}$ \\
\hline $\mathrm{PD}_{3} \mathrm{NF}_{4}$ & 6482.70 & 45378.90 & 10044.00 & 35334.90 & $\mathrm{D}$ \\
\hline $\mathrm{PD}_{1} \mathrm{NF}_{2}$ & 5344.20 & 37409.40 & 10579.98 & 26829.42 & $\mathrm{D}$ \\
\hline $\mathrm{PD}_{2} \mathrm{NF}_{4}$ & 5798.70 & 40590.90 & 11400.00 & 29190.90 & $\mathrm{D}$ \\
\hline $\mathrm{PD}_{1} \mathrm{NF}_{3}$ & 6604.20 & 46229.40 & 12119.98 & 34109.42 & $\mathrm{D}$ \\
\hline $\mathrm{PD}_{1} \mathrm{NF}_{4}$ & 5573.70 & 39015.90 & 13659.98 & 25355.92 & $\mathrm{D}$ \\
\hline
\end{tabular}

3.7. Partial Budget Analysis. Partial budget analysis on plant density with $\mathrm{N}$ fertilizer is shown in Table 3 . The highest net benefits of ETB $48835.44 \mathrm{ha}^{-1}$ and marginal rate of return $1289.85 \%$ were obtained from plant density of 66666 plants $\mathrm{ha}^{-1}$ with application rates of $92 \mathrm{~kg} \mathrm{~N} \mathrm{ha}^{-1}$. The marginal rate of returns of 255.09 and $564.80 \%$ was obtained from a plant density of 80000 plants ha ${ }^{-1}$ with application rates of 46 and $0 \mathrm{~kg} \mathrm{Nha}^{-1}$, respectively. The economic net benefit of ETB 44464.9 and $47395.9 \mathrm{ha}^{-1}$ was achieved from plant density of 100000 and 80000 plants ha $^{-1}$, respectively, with application rates of $92 \mathrm{~kg} \mathrm{~N} \mathrm{ha}^{-1}$. This indicates that $\mathrm{N}$ fertilizer at $92 \mathrm{~kg} \mathrm{ha}^{-1}$ with different plant densities was given higher economic benefits. Generally, the application of $92 \mathrm{~kg} \mathrm{Nha}^{-1}$ with 66,666 plants $\mathrm{ha}^{-1}$ resulted in optimum and profitable root yield. With higher $\mathrm{N}$ prices, it becomes more important to fertilize at the most economic rate, which may differ from the agronomic rate. Kiprono et al. [53] found that the economic optimum nitrogen rate changes as market costs and returns change.

\section{Conclusions}

The current investigation showed that the interaction effects of plant density and nitrogen fertilizer rates significantly influence root yield and root length whereas root fresh mass, root diameter, and total soluble solute were influenced by the main effects. The highest root yield of beetroot was achieved from the combination of 66666,80000 , and 100000 plant ha $^{-1}$ with $92 \mathrm{~kg} \mathrm{Nha}^{-1}$ whereas the lowest root yield of beet was obtained from the combination of $0 \mathrm{~kg} \mathrm{Nha}^{-1}$ with a planting density of 133333 plants ha ${ }^{-1}$. The economic analysis showed that higher net benefit and marginal rate of return were obtained from the application of $92 \mathrm{~kg} \mathrm{~N} \mathrm{ha}^{-1}$ with plant densities of 66666 plants $\mathrm{ha}^{-1}$. So, in order to prevent excessive production costs, the use of 66666 plants $\mathrm{ha}^{-1}$ combined with the application of $92 \mathrm{~kg} \mathrm{Nha}^{-1}$ is recommended because it is economic. Further experiments should be conducted considering different combinations of nutrients to fully exploit the yield performance of beetroot under our study area conditions. 


\section{Data Availability}

The datasets used to support the findings of this study are available at the hands of corresponding author upon request.

\section{Conflicts of Interest}

The authors declare that they have no conflicts of interest.

\section{Acknowledgments}

The authors would like to thank Arba Minch University for funding this research and their special gratitude is extended to Gircha Highland Fruits and Vegetables Research Center Directorate Office for continuous follow-up during the entire research period. We gratefully acknowledge the immense contribution made by the College of Agricultural Sciences Dean's office and the finance department for their sense of affiliation to the project.

\section{References}

[1] P. Deuter and T. Grundy, "Beetroot commercial production and processing. Food and agricultural research council, reduit, Mauritius," Acta Horticulturae, vol. 14, pp. 259-263, 2004.

[2] P. O. Ado, "Beetroot cultivation," Beetroot and Eggplant Newsletter, vol. 18, pp. 21-24, 1999.

[3] S. Surender, Agro Meteorological Requirements for Sustainable Vegetable Crops Production, CCS Haryana Agricultural University, Haryana, India, 2013, https://www.researchgate. net/publication/323600158.

[4] A. A Szopińska and M. Gawęda, "Comparison of yield and quality of red beet roots cultivated using conventional, integrated and organic method," Journal of Horticultural Research, vol. 21, no. 1, pp. 107-114, 2013.

[5] B. A. Babaji, Y. B. Ibrahim, M. A. Mahadi, M. M Jaliya, R. A. Yahaya, and A. L. Sharifai, "Response of extra- early maize (Zeamays) to varying intra- row spacing and hill density," Global Journal of Bio science and Biotechnology, vol. 1, no. 1, pp. 110-115, 2012.

[6] N. K. Fageria, "Nitrogen harvest index and its association with crop yields," Journal of Plant Nutrition, vol. 37, pp. 795-810, 2014.

[7] R. P. Freckleton, A. R. Watkinson, D. J. Webb, and T. H. Thomas, "Yield of beetroot in relation to weather and nutrients," Agricultural and Forest Meteorology, vol. 93, pp. 39-51, 1999.

[8] C. Ramazan, "Root yield and quality of sugarbeet in relation to sowing date, plant population and harvesting date interactions," Turkish Journal of Agriculture and Forestry, vol. 26, pp. 133-139, 2002.

[9] T. Sogut and H. Arioglu, "Plant density and sowing date effects on sugar beet yield and quality," Journal of Agronomy, vol. 3, pp. 215-218, 2004.

[10] E. A. E. Nemeat-Alla, K. A. Abou Shady, and N. O. Youssef, "Sugar beet yield and quality as affected by cultivating patterns and nitrogen levels," Journal of Agricultural Science, Mansoura University, vol. 32, no. 10, pp. 8069-8078, 2007.

[11] M. S. Bhullar, S. K. Uppal, and M. L. Kapur, "Influence of planting density and nitrogen does on root and sugar yoield of beet (Beta vulgaris L.) under sub-tropical semiarid conditions of Punjab," Journal of Research Punjab Agricultural University, vol. 47, no. 1/2, pp. 14-17, 2010.

[12] S. M. Salfina, M. M. Martin, S. Puffy, and S. Dharini, "Nitrogen application and leaf harvesting improves yield and nutritional quality of beetroot," American Society for horticultural Science, vol. 27, no. 3, pp. 337-347, 2017.

[13] M. Petek, M. H. Custic, N. Toth et al., "Nitrogen and crude proteins in beetroot (Beta vulgaris var. conditiva) under different fertilization treatments," Notulae Botanicae Horti Agrobotanici Cluj-Napoca, vol. 40, pp. 215-219, 2012.

[14] O. Boussadia, K. Steppe, H. Zgallai, and M. C. Van Labeke, "Effects of nitrogen deficiency on leaf photosynthesis, carbohydrates status and biomass production in two olive cultivars "Meski" and "Koroneiki"” Scientia Horticulturae, vol. 123, pp. 336-342, 2010.

[15] R. Mikkelsen and T. K. Hartz, "Nitrogen sources for organic crop production," Better Crops with Plant Food, vol. 92, no. 4, pp. 16-19, 2008.

[16] A. A. Najm, M. R. Haj SeyedHadi, M. T. Darzi, and F. Fazeli, "Influence of nitrogen fertilizer and cattle manure on the vegetative growth and tuber production of potato," The International Journal of Agriculture and Crop Sciences, vol. 5, pp. 147-154, 2013.

[17] G. Johnson, Excess Nitrogen and Vegetables and Fruits, University of Delaware, Newark, NJ, USA, 2014.

[18] A. A. El-Hosary, M. I. Salwau, A. M. M. Saad, I. H. ElGeddawy, and B. S. Ibrahim, "Sugar beet yield and its components as affected by sowing date, mineral-N and biofertilizers," Egypt Journal of Applied Science, vol. 25, no. 8, pp. 349-366, 2010.

[19] H. M. Sarhan, M. A. E. Abdou, and H. M. Al-Sayed, "Effect of planting systems, plant density and nitrogen fertilizer levels on productivity and quality of sugar beet," Journal of Plant Production, Mansoura University, vol. 3, no. 10, pp. 25672580, 2012.

[20] S. E. Seadh, "Maximizing sugar beet yields with decreasing mineral fertilizer levels pollution N," International Journal of Agricultural Sciences, vol. 4, no. 7, pp. 293-298, 2012.

[21] S. R. A. Khalil, "Study of performance and behavior of some sugar beet varieties under different environmental conditions," Ph. D. Thesis, Facuality of Agriculture, Fayoum University, Faiyum, Egypt, 2010.

[22] M. A. Abdou, A. Shimaa, and A. Badawy, "Sugar beet productivity and quality as affected by $\mathrm{N}$ - levels and irrigation with holding date Minufiya," Journal of Agricultural Research, vol. 39, no. 1, pp. 181-189, 2014.

[23] M. M. Ouda, "Effect of chemical and bio-fertilizer of nitrogen and boron on yield and quality of sugar beet," Zagazig Journal of Agricultural Research, vol. 34, no. 1, pp. 1-11, 2007.

[24] M. A. Abdou, "Effect of nitrogen fertilizer levels and harvesting dates on sugar beet productivity and quality in newly reclaimed sandy soils," Journal of Plant Production, Mansoura University, vol. 4, no. 12, pp. 1871-1882, 2013.

[25] Z. R. Moustafa, N. M. Shafika, G. B. Maria, and K. A. Aboushady, "Influence of nitrogen fertilizer on some quality, technological aspects, productivity and amino acids accumulation of sugar beet," Journal of Agricultural Science, vol. 25, no. 8, pp. 4795-4806, 2000.

[26] S. E. Seadh, "Agricultural studies on sugar beet crop," $\mathrm{Ph}$. D. Thesis, Faculty of Agriculture. Mansoura University, Mansoura, Egypt, 2004.

[27] EHDA (Ethiopian Horticulture Development Agency), "Exporting Fruit and Vegetables from Ethiopia: assessment of development potentials and investment options in the export- 
oriented fruit and vegetable sector," Technical Report, EHDA, Addis Ababa, Ethiopia, 2011.

[28] S. Hussen and Y. Muluneh, Enhancing Communities' Adaptive Capacity to Climate Change in Drought-Prone Hotspots of the Blue Nile Basin in Ethiopia, Training Manual on High Land Fruit and Vegetable Production Prepared for Extension Workers and Farmers at Kabe Water Shed, Wollo University, Dessie, Ethiopia, 2013.

[29] W. Haile and S. Boke, "Response of Irish potato (Solanum tuberosum) to the application of potassium at acidic soils of Chencha, Southern Ethiopia," International Journal of Agriculture and Biology, vol. 13, no. 4, pp. 595-598, 2011.

[30] F. Seifu and E. Betewulign, "Evaluation of released and local potato (Solanum tuberosum L.) varieties for growth performance," Journal of Agronomy, vol. 16, pp. 40-44, 2017.

[31] SAS Institute, Statistical Analytical Systems SAS/STAT User's Guide Version 9(1) caryNC, SAS institute Inc, Cary, NC, USA, 2007.

[32] K. N. Gomez and A. A. Gomez, Statistical Procedures for Agricultural Researchp. 68, 2nd edition, John Wiley \& Sons, New York, NY, USA, 1984.

[33] CIMMYT (International Maize and Wheat Improvement Center), From Agronomic Data to Farmer Recommendations: An Economics Training Manual, CIMMYT, Mexico City, Mexico, 1988.

[34] K. B. Mekuannet, "Growth, yield-related traits and yield of lowland maize (Zea mays L.) varieties as influenced by inorganic NPS and N fertilizer rates at babile, eastern Ethiopia," International Journal of Agronomy, vol. 2020, Article ID 8811308, 11 pages, 2020.

[35] G. S. Jambukar and S. S. Wange, "Studies on diazotrophic inoculation under graded levels of nitrogen in beetroot crop," Journal of Maharashtra Agricultural Universities, vol. 31, no. 1, pp. 97-99, 2006.

[36] A. A. Leilah, M. A. Badawi, E. M. Said, M. H. Ghonema, and M. A. E. Abdou, "Effect of planting dates, plant population and nitrogen fertilization on sugar beet productivity under the newly reclaimed sandy soils in Egypt," Scientific Journal of King Faisal University (Basic and Applied Sciences), vol. 6, no. 1, pp. 95-110, 2005.

[37] A. Hamidia, N. Khodabandehb, and A. D. Mohammadynasabc, "Plant density and nitrogen effects on sometraits of maize (Zea mays L.)," Plant Ecophysiology, vol. 2, pp. 47-52, 2010.

[38] M. Khaiti, "Effect of irrigation and plant density on the yield and technological characters of sugar beet," Advances in Natural and Applied Sciences, vol. 6, no. 6, pp. 886-892, 2012.

[39] P. Sadre, A. Soleymani, and H. R. Javanmard, "Root yield and quality traits of sugar beet (Beta vulgaris L.) in relation to nitrogen fertilizer and plant density in isfahan region," The International Journal of Agriculture and Crop Sciences, vol. 4, no. 20, pp. 1504-1507, 2012.

[40] M. E. Mustafa, "Effect of nitrogen and phosphorus fertilization on the performance of three sugar beet (Beta vulgaris L.) cultivars," M. Sc. Thesis, Faculty of Agriculture, University of Khartoum, Khartoum, Sudan, 2007.

[41] G. A. Amin, A. B. Elham, and M. H. M. Afifi, "Root yield and quality of sugar beet (Beta vulgaris L.) in response to biofertilizer and foliar application with micronutrients," World Applied Sciences Journal, vol. 27, no. 11, pp. 1385-1389, 2013.

[42] M. Qodliyati, Supriyono, and S. Nyoto, "Influence of spacing and depth of planting to growth and yield of arrowroot (Maranthaarundinacea)," Earth and Environmental Science, vol. 142, pp. 12-035, 2018.
[43] M. E. Khogali, Y. M. I. Dagash, and M. G. EL-Hag, "Productivity of fodder beet (Beta vulgaris Var.Crassa) cultivars affected by nitrogen and plant spacing," Agriculture and Biology Journal of North America, vol. 2, pp. 791-798, 2011.

[44] M. Turk, "Effects of fertilization on root yield and quality of fodder beet (Beta vulgaris var.crassamansf.)," Bulgarian Journal of Agricultural Science, vol. 16, no. 2, pp. 212-219, 2010.

[45] S. A. A. Basal, A. A. Zohry, and B. S. Farghaly, "Effect of tillage systems, hill spaces and potassium levels on growth and productivity of fodder beet," Zagazig Journal of Agricultural Research, vol. 29, no. 5, pp. 1379-1393, 2002.

[46] M. E. Kogali, Y. M. Ibrahim, and M. G. El Hag, "Effect of nitrogen and spacing on growth of fodder beet [B.vulgaris (L.) var. Crassa] cultivars under Sudan conditions," Journal of Pharmaceutical and Scientific Innovation, vol. 1, no. 3, pp. 67-71, 2012.

[47] J. Heitholt and G. Sassenrath-Cole, "Inter-plant competition: growth responses to plant density and row spacing," in Physiology of Cotton, J. M. Stewart, D. M. Oosterhuis, J. J. Heitholt, and J. R. Mauney, Eds., Springer, Dordrecht, The Netherlands, 2010.

[48] M. S. Jilani, T. Burki, and K. Waseem, "Effect of nitrogen on growth and yield of radish," Journal of Agricultural Research, vol. 48, no. 2, pp. 219-225, 2010.

[49] A. A. Leilah, M. A. Abdel-Moneam, G. A. Shalaby, M. A. E. Abdou, and H. M. Abdel-Salam, "Effect of plant population and distribution and nitrogen levels on yield and quality of sugar beet," Journal of Plant Production, Mansoura University, vol. 8, no. 5, pp. 591-597, 2017.

[50] J. K. Kirimi, F. M. Itulya, and V. N. Mwaja, "Effects of nitrogen and spacing on fruit yield of tomato," African Journal of Horticultural Science, vol. 5, pp. 50-60, 2011.

[51] S. Hailu, T. Seyoum, and N. Dechessa, "Effect of combined application of organic $\mathrm{P}$ and inorganic $\mathrm{N}$ fertilizers on postharvest quality of carrot," African Journal of Biotechnology, vol. 7, no. 13, pp. 2187-2196, 2008.

[52] E. I. El-Sarag and S. H. Moselhy, "Response of sugar beet quantity and quality to nitrogen and potassium fertilization under sandy soil conditions," Asian Journal of Crop Science, vol. 5, pp. 295-303, 2013.

[53] K. P. Kiprono, J. K. Wanyoko, D. M. Kamau, and W. Chepng'eno, "Economics of nitrogen fertilizer use in tea," Tea, vol. 31, no. 2, pp. 36-43, 2010. 